\title{
PENGARUH CITRA MEREK, KUALITAS PELAYANAN DAN PERSEPSI HARGA TERHADAP KEPUASAN MAHASISWA DI UNIVERSITAS MUHAMMADIYAH TANGERANG
}

\author{
${ }^{1}$ Ade Indra Permana, ${ }^{2 M u l k y ~ F a u z a n, ~ \& ~}{ }^{3}$ Sugeng L. Prastowo \\ 1,3Universitas Islam Syekh Yusuf \\ ${ }^{2}$ Universitas Mercubuana
}

\begin{abstract}
.
This study aims to analyze the influence of brand image, service quality, and perceived price and its implication towards student satisfaction in Universitas Muhammadiyah Tangerang (UMT). This research is quantitative in nature. Both primary and secondary data were obtained from various source such as journals. Primary data were gathered using questionnaire which were distributed to the target respondent. The population consists of active students from Faculty of Engineering and Faculty of Economy actively studying in 2017 using a purposive sampling. Total sample of 100 students were obtained. Data were analyzed using SPSS version 23 . The research found that the brand image, service quality and perceived price are affecting students satisfaction of Universitas Muhammadiyah Tangerang. Researcher suggests UMT to improve their brand image, also to improve administration services and lecturer quality. In addition UMT shall adjust their tuition costing structure to win the competition in pricing.
\end{abstract}

Keywords: Brand Image, Customer Satisfaction, Marketing management services, Perceived Price, Service Quality. 


\begin{abstract}
Abstrak.
Penelitian ini bertujuan untuk menganalisis pengaruh Citra Merek, Kualitas Layanan dan Persepsi Harga Terhadap Kepuasan Mahasiswa di Universitas Muhammadiyah Tangerang (UMT). Penelitian bersifat kuantitatif dan bersifat explanatory, sedangkan teknik pengumpulan data berdasarkan kuesioner dan dokumen. Populasi penelitian ini adalah mahasiswa dari fakultas teknik dan fakultas ekonomi yang aktif berkuliah pada tahun 2017. Metode pengambilan sample menggunakan metode probability sampling dan teknik pengambilan sampel dengan menggunakan simple random sampling. Penentuan ukuran sampel menggunakan rumus Slovin dengan tingkat kesalahan 10\% berjumlah 100 mahasiswa yang diambil sebagai responden. Data yang terkumpul dianalisa menggunakan SPSS versi 23. Hasil penelitian ditemukan bahwa Citra Merek, Kualitas Layanan dan Persepsi Harga secara signifikan berpengaruh terhadap Kepuasan Mahasiswa di UMT. Peneliti menyarankan UMT perlu meningkatkan citra merek, dan juga melakukan peningkatan di kualitas staf administrasi dan pengajar. Selain itu UMT perlu meninjau kembali biaya perkuliahan yang dikenakan ke mahasiswa agar dapat meningkatkan daya saing.
\end{abstract}

Kata kunci: Citra Merek, Kepuasan Pelanggan, Kualitas Pelayanan, Manajemen Pemasaran Jasa, Persepsi Harga. 


\section{A. Pendahuluan}

Meningkatnya minat masyarakat terhadap pendidikan tinggi telah melahirkan fenomena baru, perguruan-perguriuan tinggi baru bermunculan dan menawarkan layanan pendidikan tinggi kepada masyarakat. Fenomena in tidak hanya menghadirkan persaingan diantara para penyedia layanan pendidikan, tetapi juga berdampak pada masyarakat sebagai target pasar yang semakin sulit menentukan perguruan tinggi yang akan dipilih, sehingga melahirkan kompetisi yang unik. Pendekatan yang dilakukan oleh para penyedia layanan pendidikan tinggi semakin berkembang dan kompleks, dari sisi tatakelola menuju organisasi yang efektif, pemasaran yang efisien menjadi syarat bagi keberhasilan layanan penyedia pendidikan untuk dapat menyintas dari kompetisi perguruan tinggi di negeri ini.

Universitas Muhammadiyah Tangerang adalah Universitas yang baru berdiri pada tahun 2009. Berdasarkan informasi dari Biro Humas Universitas Muhammadiyah Tangerang, UMT mencatat performa yang sangat baik dalam mendapatkan calon mahasiswa. Terlihat pada gambar

1. Jumlah mahasiswa UMT terus meningkat dari tahun ke tahun.

Namun, berdasarkan hasil pemeringkatan dari Kementerian Riset Teknologi dan Pendidikan Tinggi Republik Indonesia (Kemenristekdikti), Universitas Muhammadiyah Tangerang menduduki peringkat 321 dari 3224 Perguruan Tinggi yang terdata oleh Kemenristekdikti. UMT bukanlah perguruan tinggi yang terbaik di kelasnya.

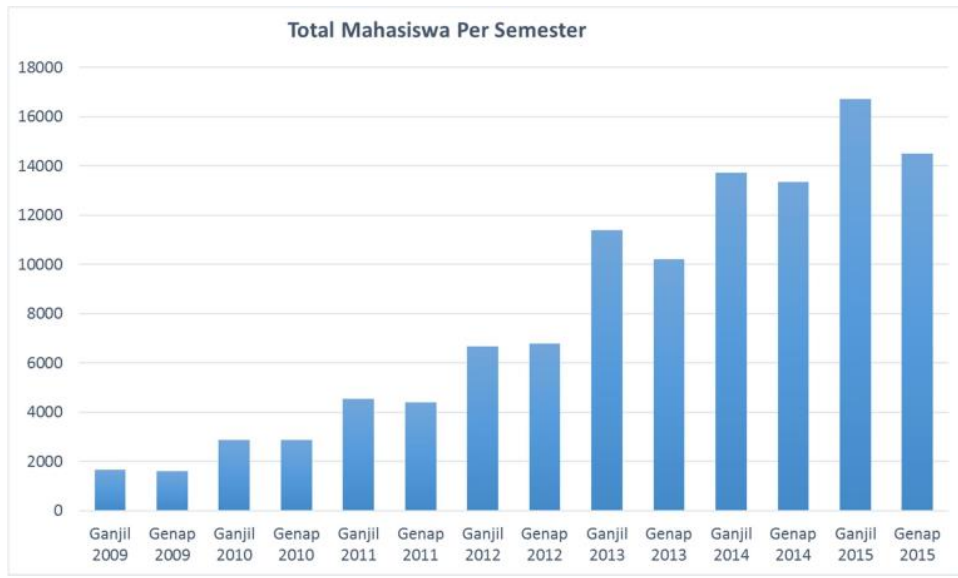

Gambar 1. Total Mahasiswa UMT dari tahun ke tahun Sumber: dikti.go.id, diolah (2017) 
Webometrics, salah satu lembaga pemeringkat universitas yang meyakini bahwa kualitas dari suatu lembaga tinggi dapat dinilai dari publikasi dan aktivitas riset yang terbuka untuk publik, telah memeringkat seluruh Universitas Muhammadiyah di Indonesia, kecuali Universitas Muhammadiyah Tangerang. QS World University Ranking, lembaga pemeringkatan dengan metode lebih komprehensif yang melibatkan reputasi akademik dan staf pengajar, rasio mahasiswa dengan program studi, referensi riset hingga rasio mahasiswa internasional juga tidak memeringkat Universitas Muhammadiyah Tangerang. Universitas Muhammadiyah tidak memiliki citra yang cukup baik di kompetisi internasional. Reputasi nasional dan internasional yang dimiliki Universitas Muhammadiyah Tangerang, jika diukur dengan peringkat di kedua lembaga pemeringkat tersebut, dapat dinilai cukup terbelakang di negeri sendiri terkhusus di antara Universitas terafiliasi Muhammadiyah lainnya. Padahal, Universitas Muhammadiyah Tangerang, sebagai Universitas yang baru dan belum berusia 10 tahun memerlukan reputasi akademik agar bisa bertahan dari persaingan perguruan tinggi di Indonesia.

Dalam proses penelitian yang dilakukan, penulis telah mengumpulkan masalah-masalah yang dihadapi oleh Universitas Muhammadiyah Tangerang. Adapun masalah-masalah yang dihadapi yaitu sebagai berikut: Lemahnya citra UMT dalam kompetisi baik di tingkat nasional ataupun internasional, dimana UMT tidak terperingkat dalam webometrics ataupun QS University Ranking, buruknya kualitas layanan baik secara fasilitas fisik ataupun respon oleh manajemen universitas terhadap permasalahan yang terjadi, adanya temuan mengenai ketidakpuasan mahasiswa terhadap biaya kuliah di UMT yang tidak sebanding dengan manfaat yang didapatkan, dan ketidakpuasan mahasiswa secara umum terhadap layanan, manajemen, dan proses akademik di UMT.

Berdasarkan uraian latar belakang yang telah dikemukakan, maka permasalahan dalam penelitian ini dapat dijabarkan sebagai berikut: Apakah citra merek berpengaruh terhadap kepuasan mahasiswa? Apakah kualitas pelayanan berpengaruh terhadap kepuasan mahasiswa? Apakah persepsi harga berpengaruh terhadap kepuasan mahasiswa? Apakah citra merek, kualitas pelayanan dan persepsi harga berpengaruh terhadap kepuasan mahasiswa? 


\section{B. Kajian Teori}

\section{Citra Merek}

Merek menjadi tanda pengenal bagi penjual atau pembuat suatu produk atau jasa. Menurut Tjiptono (2006:27) secara teknis apabila seorang pemasar membuat nama, logo atau simbol baru, maka ia telah menciptakan sebuah merek. Citra terhadap merek berhubungan dengan sikap yang berupa keyakinan dan preferensi terhadap suatu merek. Konsumen yang memiliki citra yang positif terhadap suatu merek, akan lebih memungkinkan untuk melakukan pembelian. Faktor- faktor pendukung terbentuknya citra merek dalam keterkaitannya dengan asosiasi merek menurut Kotler \& Keller (2009:336) adalah Favorability of brand association atau keunggulan asosiasi merek, salah satu faktor pembentuk citra merek adalah keunggulan produk, dimana produk tersebut unggul dalam persaingan, Strength of brand association atau kekuatan asosiasi merek, setiap merek yang berharga mempunyai jiwa, suatu kepribadian khusus adalah kewajiban mendasar bagi pemilik merek untuk dapat mengungkapkan, mensosialisasikan jika kepribadian tersebut dalam satu bentuk iklan ataupun bentuk kegiatan promosi dan pemasaran lainnya. Hal itulah yang akan terus menerus menjadin penghubung antara produk atau merek dengan konsumen. Dengan demikian produk tersebut akan cepat dikenal dan tetap terjaga ditengah tengah maraknya persaingan, dan Uniquesness of brand association atau keunikan suatu merek, merupakan keunikan keunikan yang dimiliki oleh produk atau merek.

\section{Kualitas Pelayanan}

Tjiptono (2011:180), kualitas jasa atau layanan merupakan ukuran seberapa baik tingkat layanan yang diberikan mampu sesuai dengan harapan pelanggan. Berdasarkan definisi ini, kualitas layanan dapat diwujudkan melalui pemenuhan kebutuhan dan keinginan pelanggan serta ketepatan penyampaiannya untuk mengimbangi harapan pelanggan. Dengan demikian ada dua faktor utama yang mempengaruhi kualitas layanan, yaitu: layanan yang diharapkan (expected service) dan layanan yang dirasakan (perceived service). Adapun dimensi kualitas layanan yang dipakai dalam penelitian ini adalah yang dikemukakan Parasuraman, Zeithaml \& Berry dalam Tjiptono (2011:198) yakni Tangibles (berwujud), meliputi tampilan fasilitas fisik, peralatan, personel, dan media komunikasi; Reliability (kehandalan), mencakup dua aspek utama, yaitu konsistensi kinerja dan dapat dipercaya. Hal ini berarti perusahaan 
harus mampu menyampaikan layanan dengan cepat, konsisten di dalam memenuhi janji, handal dan akurat di dalam menyimpan data; Responsiveness (ketanggapan), yaitu kemampuan untuk membantu pelanggan dalam memberikan jasa dengan segera dan tanggap; Assurance (jaminan), mencakup pengetahuan, kesopanan, dan kemampuan untuk menimbulkan kepercayaan dan keyakinan pelanggan; Empathy, meliputi kemudahan dalam melakukan hubungan komunikasi, memberikan perhatian dengan tulus terhadap kebutuhan pelanggan.

\section{Persepsi Harga}

Persepsi harga (perceived price) berkaitan dengan bagaimana informasi harga dipahami seluruhnya oleh konsumen dan memberikan makna yang dalam bagi mereka. Pendekatan untuk memahami persepsi harga adalah pemahaman pemrosesan informasi oleh konsumen. Menurut Kotler (2008:278), terdapat tiga indikator di dalam persepsi harga, yaitu keterjangkauan, apakah suatu harga yang ditawarkan terjangkau dengan daya beli target konsumen atau sesuai dengan budget yang telah ditentukan; daya saing harga, yaitu apakah suatu harga yang ditawarkan kompetitif dibandingkan dengan produk atau jasa lainnya, atau mungkin lebih murah; dan kesesuaian harga dengan manfaat, yaitu bagaimana nilai manfaat yang diterima pelanggan atas produk atau jasa dianggap sesuai dengan biaya yang dikeluarkan.

\section{Kepuasan Mahasiswa}

Lovelock dan Wirtz (2007:102) mendefinisikan kepuasan sebagai keadaan emosional, reaksi pasca pembelian dapat berupa kemarahan, ketidakpuasan, kejengkelan, netralitas, kegembiraan, atau kesenangan. Kepuasan pelanggan merupakan suatu perasaan atau penilaian emosional dari pelanggan ketika harapan dan kebutuhan terpenuhi atas penggunaan produk atau jasa suatu perusahaan. Dengan kata lain, jika konsumen merasa apa yang diperoleh lebih rendah dari yang diharapkan maka konsumen tersebut akan tidak puas. Jika yang diperoleh konsumen melebihi apa yang diharapkan maka konsumen akan puas, sedangkan pada keadaan ketika apa yang diterima sama dengan apa yang diharapkan, maka konsumen tersebut akan merasakan puas dan tidak puas (netral). Adapun dimensi dalam penelitian ini menggunakan landasan teori oleh Forner dan Glenmick dalam Kotler (2005:177), yaitu persepsi perbandingan kinerja suatu produk atau jasa dengan harapan konsumen, dimana terdiri dari empat indikator persepsi kepuasan pelanggan, yaitu: persepsi kepuasan terhadap kualitas produk atau 
jasa, persepsi kepuasan terhadap tenaga layanan jasa, persepsi kepuasan terhadap harga yang ditawarkan, persepsi kepuasan layanan secara keseluruhan.

\section{Kerangka Pemikiran}

Kerangka pemikiran dalam penelitian ini seperti terlihat berikut ini:

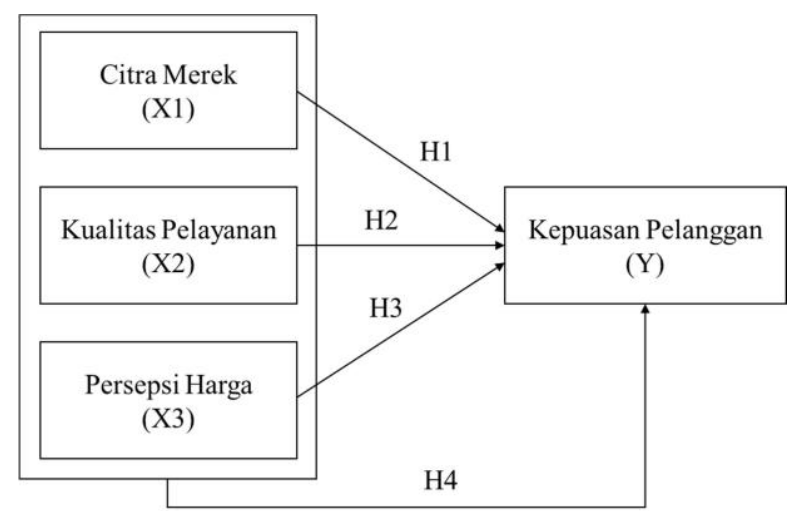

Gambar 2. Kerangka Pemikiran Penelitian

$\mathrm{H} 1=$ Pengaruh citra merek terhadap kepuasan pelanggan .

$\mathrm{H} 2=$ Pengaruh kualitas pelayanan terhadap kepuasan pelanggan .

$\mathrm{H} 3=$ Pengaruh persepsi harga terhadap kepuasan pelanggan .

$\mathrm{H} 4=$ Pengaruh citra merek, kualitas pelayanan, dan persepsi harga secara bersama-sama terhadap kepuasan pelanggan.

Kerangka pemikiran ini dapat dinyatakan dalam persamaan linier dengan persamaan berikut:

$$
Y=\beta_{0}+\beta_{1} X_{1}+\beta_{2} X_{2}+\beta_{2} X_{3}+\varepsilon
$$

Dimana:

1. Y adalah kepuasan mahasiswa

2. Bo adalah konstanta

3. $\beta 1$ adalah variabel dari Citra Merek (X1).

4. $\quad \beta 2$ adalah variabel dari Kualitas Pelayanan (X2).

5. $\beta 3$ adalah variabel dari Persepsi Harga (X3).

6. $\varepsilon$ adalah nilai error 
Berdasarkan kerangka pemikiran tersebut, maka hipotesis yang diajukan dalam penelitian ini adalah:

H1: citra merek mempunyai pengaruh positif terhadap kepuasan pelanggan.

H2: kualitas pelayanan mempunyai pengaruh positif terhadap kepuasan pelanggan.

H3: persepsi harga mempunyai pengaruh positif terhadap kepuasan pelanggan.

H4: Citra merek, kualitas pelayanan, dan persepsi harga secara bersama-sama mempunyai pengaruh positif terhadap kepuasan mahasiswa.

\section{Metode}

Penelitian ini menggunakan desain penelitian kausalitas. Desain penelitian kausal digunakan untuk membuktikan hubungan antara sebab dan akibat dari beberapa variabel. Jika model hanya mengunakan sebuah variabel, maka dapat digunakan teknik regresi, namun jika lebih dari satu variabel dependen, maka regresi tidak cukup sehingga diperlukan teknik lain. Penelitian ini merupakan studi lapangan yang menggunakan metode kuantitatif, dengan menggunakan kuesioner sebagai alat pengumpulan data (penelitian survey) dan menggunakan analisis statistik yang akan diolah dengan menggunakan SPSS.

Variabel yang digunakan dalam penelitian ini adalah sebagai berikut:

1. Variabel Independen: Citra Merek, Kualitas Pelayanan dan Persepsi Harga. Menurut Sugiyono (2008:39) variabel independen adalah variabel yang mempengaruhi atau yang menjadi sebab perubahannya atau timbulnya variabel dependen (terikat).

2. Variabel Dependen: Kepuasan Pelanggan. Menurut Sugiyono (2008:40) variabel dependen adalah variabel yang dipengaruhi atau yang menjadi akibat, karena adanya variabel bebas. Dalam penelitian ini variabel dependennya adalah Kepuasan Pelanggan.

Definisi operasional ialah suatu definisi yang didasarkan pada karakteristik yang dapat diobservasi dari apa yang sedang didefinisikan. Berikut adalah tabel yang merangkum definisi operasional: 
PENGARUH CITRA MEREK, KUALITAS PELAYANAN DAN PERSEPSI HARGA

TERHADAP KEPUASAN MAHASISWA DI UNIVERSITAS MUHAMMADIYAH

TANGERANG

Ade Indra Permana, Mulky Fauzan, E Sugeng L. Prastowo

Tabel 1. Definisi Operasional Variabel Penelitian

\begin{tabular}{|c|c|}
\hline Variabel & Definisi \\
\hline Citra Merek (X1) & $\begin{array}{l}\text { Suatu bayangan atau gambaran yang ada } \\
\text { didalam benak seseorang yang timbul karena } \\
\text { emosi dan reaksi terhadap lingkungan } \\
\text { sekitarnya. (Sopiah \& Syihabudhin, 2008). }\end{array}$ \\
\hline Kualitas Pelayanan (X2) & $\begin{array}{l}\text { Aktivitas atau serangkaian aktivitas yang } \\
\text { bersifat tidak kasat mata yang terjadi sebagai } \\
\text { akibat adanya interaksi antara konsumen } \\
\text { dengan staf atau hal-hal lain yang disediakan } \\
\text { oleh perusahaan pemberi dengan staf atau hal- } \\
\text { hal lain yang disediakan oleh perusahaan } \\
\text { pemberi pelayanan yang dimaksud untuk } \\
\text { memecahkan permasalahan konsumen/ } \\
\text { pelanggan (Gronroos dalam Srivastava Medha } \\
\text { \& Rai, Alok Kumar, 2013). }\end{array}$ \\
\hline Persepsi Harga (X3) & $\begin{array}{l}\text { Sejumlah uang yang dibebankan atas suatu } \\
\text { produk atau jasa, atau jumlah dari nilai tukar } \\
\text { konsumen atas manfaat-manfaat karena } \\
\text { memiliki atau menggunakan produk atau jasa } \\
\text { tersebut. (Kotler, 2009). }\end{array}$ \\
\hline Kepuasan Pelanggan (Y) & $\begin{array}{l}\text { Perasaan senang atau kecewa seseorang yang } \\
\text { muncul setelah membandingkan kinerja (hasil) } \\
\text { produk/jasa terhadap kinerja yang diharapkan } \\
\text { (Kotler, 2009) }\end{array}$ \\
\hline
\end{tabular}

Sumber: berbagai sumber pustaka.

Tabel pengukuran variabel penelitian dapat dilihat pada tabel berikut ini:

Tabel 2. Pengukuran Variabel Penelitian

\begin{tabular}{lll}
\multicolumn{1}{c}{ Variabel } & \multicolumn{1}{c}{ Dimensi } & \multicolumn{1}{c}{ Indikator } \\
\hline Citra Merek (X1) & & 1. Dikenal \\
Keller (2009) & $\begin{array}{l}\text { 1. Favorability of Brand } \\
\text { Association }\end{array}$ & $\begin{array}{l}\text { 2. Reputasi } \\
\text { 3. Lokasi Strategis }\end{array}$ \\
& $\begin{array}{l}\text { 2. Strength of Brand } \\
\text { Association }\end{array}$ & $\begin{array}{l}\text { 1. Berkualitas } \\
\text { 2. Partisipasi dalam dunia }\end{array}$ \\
& $\begin{array}{l}\text { 3. Unademik } \\
\text { 3. Uniqueness of Brand } \\
\text { Association }\end{array}$ & $\begin{array}{l}\text { 1. Logo } \\
\text { 2. Mudah Diucap }\end{array}$ \\
& & 3. Mudah Dingat
\end{tabular}

129I Pelita - Jurnal Penelitian dan Karya Ilmiah 


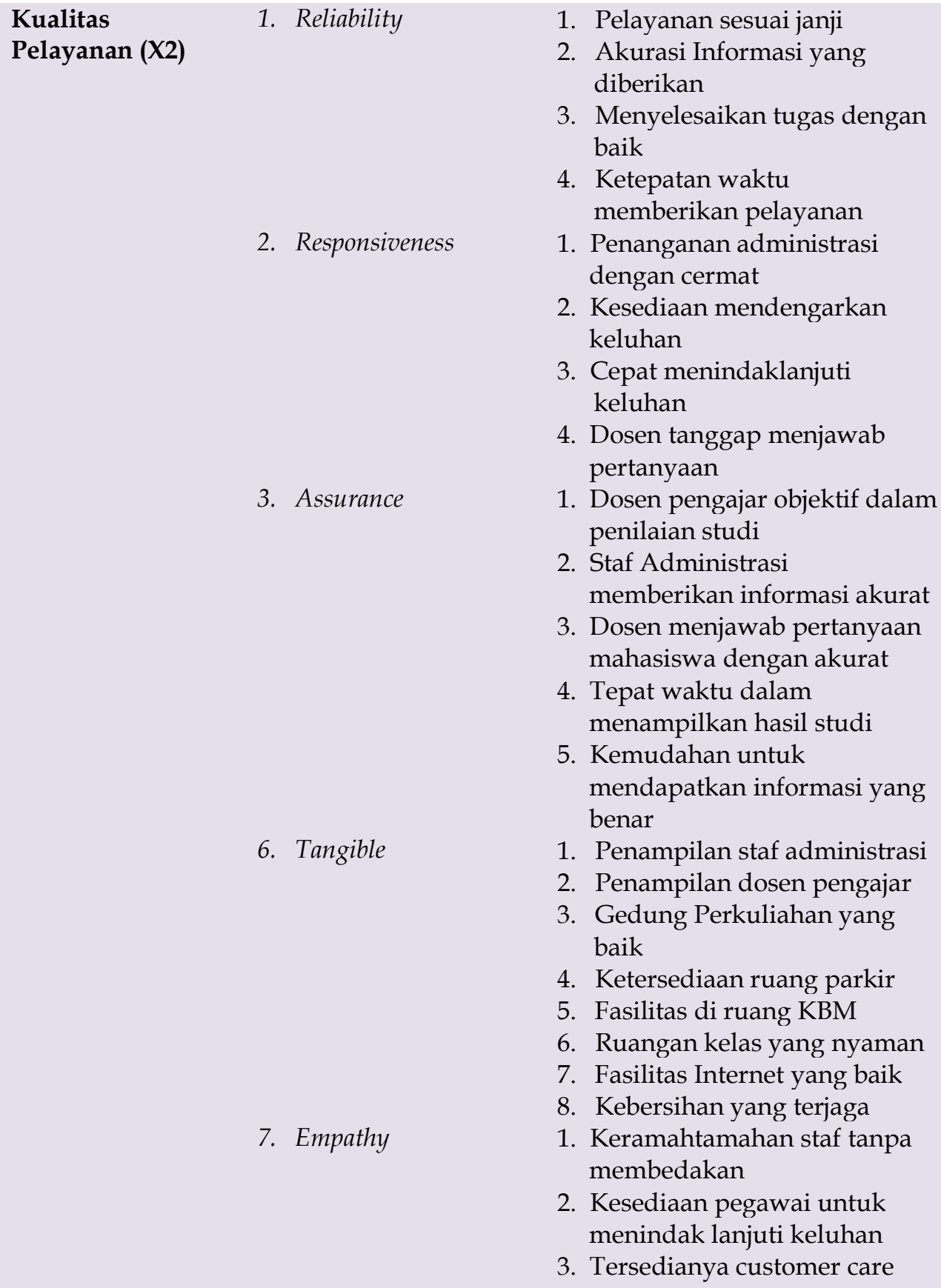




\section{Persepsi Harga}

(X3)

Kotler (2009)

Kepuasan

Pelanggan (Y)

(Kotler 2008)
1. Keterjangkauan Harga

2. Kesesuaian harga dengan manfaat

3. Harga kompetitif

1. Biaya pendaftaran terjangkau

2. Biaya rutin kuliah terjangkau

1. Harga sesuai dengan jasa yang didapatkan

2. Harga sesuai dengan fasilitas fisik yang didapatkan

1. Biaya pendaftaran bersaing dengan kompetitor

2. Biaya rutin bersaing dengan kompetitor

1. Pelayanan sesuai dengan harapan

2. Sistem Administrasi sesuai dengan harapan

2. Kesan

1. Staf administrasi yang kompeten

2. Puas dengan proses KBM oleh dosen

Sumber : Data Sekunder Diolah (2015)

\section{Sumber Data}

Data primer merupakan data yang dikumpulkan sendiri oleh perorangan atau langsung melalui obyeknya. Data primer secara khusus dikumpulkan untuk menjawab pertanyaan penelitian (Sugiyono, 2002). Pengumpulan data ini biasanya dilakukan dengan membagikan kuesioner kepada obyek penelitian dan diisi secara langsung oleh responden.

Data sekunder adalah data yang diperoleh secara tidak langsung atau melalui media perantara. Data sekunder biasanya telah dikumpulkan oleh lembaga pengumpul data dan dipublikasikan kepada masyarakat pengguna data (Sugiyono, 2002). Data yang didapatkan dari arsip yang dimiliki organisasi/instansi, studi pustaka, penelitian terdahulu, literatur, dan jurnal yang berhubungan dengan permasalahan yang diteliti. Data sekunder berupa jenis kelamin mahasiswa, dan tingkatan studi mahasiswa.

\section{Teknik Pengumpulan Data}

Teknik Pengumpulan Data merupakan teknik atau cara yang dilakukan untuk mengumpulkan data. Metode menunjuk suatu cara sehingga dapat diperlihatkan penggunaannya melalui angket, wawancara, 
pengamatan, tes, dokumentasi dan sebagainya. Teknik pengumpulan data yang digunakan dalam penelitian ini adalah kuesioner yang dikumpulkan dengan menggunakan kuesioner kepada responden, baik secara langsung maupun contact person; dan wawancara, dengan cara menggunakan pertanyaan lisan kepada subyek penelitian. Hal ini dilakukan untuk mendapatkan gambaran dari permasalahan yang biasanya terjadi karena sebab- sebab khusus yang tidak dapat dijelaskan dengan kuesioner.

\section{Populasi dan Sampel}

Populasi yang ideal dituju ditempat penelitian adalah mahasiswa Universitas Muhammadiyah Tangerang, dengan target sebaran bebas sebanyak 30.000 mahasiswa. Dalam studi kasus ini, penulis membatasi pada dua program studi dengan mahasiswa terbanyak, yakni: Manajemen (1.939 mahasiswa), Teknik Informatika (1.731 mahasiswa), dengan total populasi adalah 3.670 mahasiswa.

Populasi yang dituju ditempat penelitian adalah mahasiswa UMT sebanyak 3.670 mahasiswa, maka dengan rumus Slovin, dengan error 10\%, didapatkan target sebanyak 100 mahasiswa dijadikan sebagai responden.

\section{Hasil d an Pembahasan}

Berdasarkan hasil penelitian, berikut adalah pengaruh citra merek, kualitas pelayanan, dan persepsi harga terhadap kepuasan mahasiswa di UMT.

Tabel 3. Pengaruh Citra Merek, Kualitas Pelayanan dan Persepsi Harga terhadap Kepuasan Mahasiswa di UMT

\begin{tabular}{lllll}
\hline \multicolumn{1}{c}{ Variabel } & $\begin{array}{c}\text { Koefisien } \\
\text { Regresi }\end{array}$ & T Hitung & Sig & Keterangan \\
\hline Konstanta & $\mathbf{- 1 , 6 7 6}$ & -1.305 & 0.195 & \\
Citra Merek (X1) & $\mathbf{0 . 2 0 1}$ & $\mathbf{3 . 0 6 9}$ & 0.003 & Signifikan \\
$\begin{array}{l}\text { Kualitas } \\
\text { Pelayanan (X2) }\end{array}$ & $\mathbf{0 . 7 0 9}$ & $\mathbf{1 1 . 2 4 2}$ & 0.000 & Signifikan \\
$\begin{array}{l}\text { Persepsi Harga } \\
\text { (X3) }\end{array}$ & $\mathbf{0 . 4 0 8}$ & $\mathbf{6 . 1 0 5}$ & 0.000 & Signifikan \\
$\mathrm{R}^{2}$ & $\mathbf{0 . 6 6 5}$ & & & \\
F Hitung & $\mathbf{6 3 . 4 7 3}$ & & 0.000 & Ha diterima \\
\hline
\end{tabular}

Dependent Variable: Kepuasan Mahasiswa

Sumber: Data Primer Diolah (2017) 
PENGARUH CITRA MEREK, KUALITAS PELAYANAN DAN PERSEPSI HARGA

TERHADAP KEPUASAN MAHASISWA DI UNIVERSITAS MUHAMMADIYAH

TANGERANG

Ade Indra Permana, Mulky Fauzan, E Sugeng L. Prastowo

Berikut adalah persamaan yang dihasilkan dari analisis regresi liner dalam penelitian ini:

$$
Y=-1.676+0,201 X_{1}+0,709 X_{2}+0,408 X_{3}
$$

Dari persamaan regresi yang terbentuk di atas dapat dijelaskan interpretasi secara matematika

sebagai berikut:

1. $\quad \beta o$ (konstanta) $=-1.676$, artinya nilai variabel kepuasan mahasiswa $(\mathrm{Y})$ sebesar -1.676 apabila variabel citra merek $\left(\mathrm{X}_{1}\right)$, variabel kualitas pelayanan $\left(X_{2}\right)$ dan persepsi harga $\left(X_{3}\right)$, tidak ada atau sama dengan nol.

2. $\beta_{1}=0,201$, artinya apabila variabel citra merek $\left(X_{1}\right)$ meningkat satu satuan dan variabel kualitas pelayanan $\left(\mathrm{X}_{2}\right)$ dan persepsi harga $\left(\mathrm{X}_{3}\right)$ tetap maka variabel kepuasan mahasiswa $(\mathrm{Y})$ akan meningkat.

3. $\beta_{2}=0,709$, artinya apabila variabel variabel kualitas pelayanan $\left(X_{2}\right)$ meningkat satu satuan dan variabel citra merek $\left(X_{1}\right)$ dan persepsi harga $\left(\mathrm{X}_{3}\right)$ tetap maka variabel kepuasan mahasiswa $(\mathrm{Y})$ akan meningkat.

4. $\beta_{3}=0,408$, artinya apabila variabel variabel persepsi harga $\left(X_{3}\right)$ meningkat satu satuan dan variabel citra merek $\left(\mathrm{X}_{1}\right)$ dan kualitas pelayanan $\left(\mathrm{X}_{2}\right)$ tetap maka variabel kepuasan mahasiswa $(\mathrm{Y})$ akan meningkat.

Berdasarkan data di atas, dapat disimpulkan bahwa kualitas pelayanan, mempunyai pengaruh yang paling besar di antara variabel penelitian yang lain. Nilai konstanta dalam persamaan regresi di atas yakni sebesar -1.676. Nilai konstanta merupakan nilai tetap, jadi jika diasumsikan citra merek bernilai 0, maka kepuasan mahasiswa akan menurun sebesar 2.594. Selain nilai konstanta, dari persamaan regresi di atas juga diketahui nilai koefisien regresi citra merek $=0,201$. Nilai ini menggambarkan besarnya kenaikan atau penurunan kualitas pelayanan yang diakibatkan oleh kenaikan satu satuan variabel citra merek. Apabila koefisien regresinya bernilai positif maka akan menyebabkan kenaikan, dan jika nilainya negatif akan menyebabkan penurunan.

Dari persamaan regresi yang diperoleh, diketahui koefisien regresinya bernilai positif $(0,201)$, sehingga menggambarkan adanya pengaruh yang searah antara citra merek dengan kepuasan mahasiswa. Setiap kenaikan satu satuan variabel citra merek menyebabkan kenaikan kinerja sebesar 0,201 pada konstanta -1.676. Hasil ini menunjukkan bahwa semakin baik citra merek, kualitas pelayanan dan persepsi harga akan 
berimplikasi pada meningkatnya kepuasan mahasiswa, dan sebaliknya semakin buruk citra merek, kualitas pelayanan dan persepsi harga, akan berakibat pada menurunnya kepuasan mahasiswa.

Nilai konstanta pada persamaan regresi yang didapat dari hasil perhitungan menunjukkan angka negatif tidaklah menjadi persoalan dan bisa diabaikan selama model asumsi klasik lainnya untuk regresi linier berganda sudah memenuhi uji asumsi klasik. Selain itu nilai konstanta bernilai negatif umumnya terjadi jika ada rentang yang cukup jauh antara variabel dependen dan variabel independen (Dougherty: 2002).

Nilai $R \quad(R$ square $)$ yang mendekati satu berarti variabel independennya memberikan hampir semua informasi yang dibutuhkan untuk memprediksi variasi - variabel dependen. Sehubungan dengan hal tersebut, maka berdasarkan hasil perhitungan koefisien determinasi disajikan pada Tabel 3. dapat dikatakan bahwa besarnya $\mathrm{R}$ atau korelasi besarnya variabel independen Citra merek $\left(\mathrm{X}_{1}\right)$, Kualitas pelayanan $\left(\mathrm{X}_{2}\right)$, dan Persepsi harga $\left(X_{3}\right)$ secara bersama- sama terhadap variabel dependen Kepuasan mahasiswa (Y) adalah sebesar 0.815 dengan tingkat hubungan sangat kuat.

$\mathrm{R}$ square atau koefisen determinan sebesar 0.665 atau 66,5\%, menunjukkan bahwa kepuasan mahasiswa dipengaruhi ketiga variabel independen yang dipakai dalam penelitian ini (yakni Citra merek $\left(\mathrm{X}_{1}\right)$, Kualitas pelayanan $\left(\mathrm{X}_{2}\right)$, dan Persepsi harga $\left(\mathrm{X}_{3}\right)$ ) sebesar $66,5 \%$, dan masih ada pengaruh dari faktor lainnya yaitu 33,5\% tidak diteliti.

Hipotesis 1. Pada Tabel 3. kolom Sig. untuk variabel Citra merek terlihat nilai Significance sebesar 0,003, lebih kecil daripada 0,05 maka dapat disimpulkan bahwa citra merek berpengaruh signifikan. Tingkat signifikansi dapat pula dilakukan pengujian dengan menggunakan uji $t$. Nilai Tabel t pada alpha 0.05 (two tail) $\mathrm{df}=\mathrm{n}-4=100-4=96$ adalah 1,98 . sedangkan nilai $t$ hitung pada Tabel diatas sebesar uji $t=3,069$. Hal ini berarti thitung $>$ tTabel, maka Ha diterima dan Ho ditolak, dengan demikian menunjukkan Citra merek berpengaruh signifikan terhadap Kepuasan mahasiswa.

Hipotesis 2. Pada Tabel 3 kolom Sig. untuk variabel Kualitas pelayanan terlihat nilai Significance sebesar 0,000, lebih kecil daripada 0,05 maka dapat disimpulkan bahwa kualitas pelayanan berpengaruh signifikan. Pengujian dengan menggunakan uji $\mathrm{t}$ adalah, nilai Tabel $\mathrm{t}$ pada alpha 0.05 (two tail) $\mathrm{df}=\mathrm{n}-4=100-2=4$ adalah 1.98 , sedangkan nilai $\mathrm{t}$ hitung pada Tabel diatas sebesar uji $t=11.242$. Hal ini berarti thitung $>$ tTabel maka Ha diterima dan Ho ditolak, dengan demikian menunjukkan 
Kualitas pelayanan berpengaruh signifikan terhadap Kepuasan mahasiswa.

Hipotesis 3. Pada Tabel 3 kolom Sig. untuk variabel Persepsi harga terlihat nilai Significance sebesar 0,000, lebih kecil daripada 0,05 maka dapat disimpulkan bahwa persepsi harga berpengaruh signifikan. Pengujian dengan menggunakan uji $\mathrm{t}$ adalah, nilai Tabel $\mathrm{t}$ pada alpha 0.05 (two tail) $\mathrm{df}=\mathrm{n}-4=100-4=96$ adalah 1.98 . sedangkan nilai $\mathrm{t}$ hitung pada Tabel diatas sebesar uji $t=6.105$. Hal ini berarti thitung $>$ TTabel maka Ha diterima dan Ho ditolak, dengan demikian menunjukkan persepsi harga berpengaruh signifikan terhadap Kepuasan mahasiswa.

Hipotesis 4. Hasil uji signifikan secara simultan dapat dilihat pada Tabel 5.23., Uji $\mathrm{F}$ dilakukan untuk mengetahui pengaruh variabel Citra merek dan Kualitas pelayanan terhadap Kepuasan mahasiswa secara simultan. Nilai Sig. sebesar 0.000 menunjukkan untuk tingkat signifikansi alpha sebesar 0.05 two tailed pasti signifikan. Sedangkan untuk pengujian dengan uji $\mathrm{F}$ adalah dengan membandingkan antara nilai $\mathrm{F}_{\text {Tabel }}$ dengan Fhitung. Nilai Fhitung sebesar 63.473, $\mathrm{F}_{\text {Tabel }}$ adalah 2.70 (lihat pada Tabel F), dengan demikian didapat hasil $\mathrm{F}$ hitung (63.473) > $\mathrm{F}_{\text {Tabel }}$ (2.70) maka Ho ditolak dan $\mathrm{H}_{\mathrm{a}}$ diterima. Oleh karena itu dapat disimpulkan bahwa Citra merek, Kualitas pelayanan dan persepsi harga berpengaruh secara simultan terhadap Kepuasan mahasiswa UMT.

Matriks korelasi antar dimensi ini dimaksudkan untuk mengetahui dimensi variabel independen yang mempunyai nilai korelasi tertinggi dengan dimensi variabel dependen atau kepuasan mahasiswa. Dimensi variabel independen yang mempunyai nilai korelasi tertinggi dengan dimensi variabel dependen atau kepuasan mahasiswa itu dilihat sebagai leverage atau faktor pengungkit. Dengan kata lain perbaikan variabel leverage ini dinilai paling efektif untuk meningkatkan kinerja. Berikut adalah matriks korelasi antar dimensi yang diuji dalam penelitian ini: 
Tabel 4. Matriks Korelasi Antar Dimensi

\begin{tabular}{|c|c|c|c|}
\hline Variabel & Dimensi & $\begin{array}{l}\text { Y (Kepuasan } \\
\text { Mahasiswa) } \\
Y_{11} \text { Harapan }\end{array}$ & $\begin{array}{c}Y_{12} \\
\text { Kesan }\end{array}$ \\
\hline \multirow{3}{*}{$\begin{array}{c}\mathrm{X} 1 \\
\text { (Citra merek) }\end{array}$} & $\begin{array}{l}\text { Favorability of } \\
\text { Brand Association }\end{array}$ & 0.293 & 0.239 \\
\hline & $\begin{array}{l}\text { Strength of Brand } \\
\text { Association }\end{array}$ & 0.393 & 0.596 \\
\hline & $\begin{array}{l}\text { Uniqueness of } \\
\text { Brand Association }\end{array}$ & 0.236 & 0.341 \\
\hline \multirow{4}{*}{$\begin{array}{c}\text { X2 } \\
\text { (Kualitas } \\
\text { pelayanan) }\end{array}$} & \multirow{4}{*}{$\begin{array}{l}\text { Reliability } \\
\text { Responsiveness } \\
\text { Assurance Tangible } \\
\text { Empathy }\end{array}$} & 0.361 & 0.608 \\
\hline & & 0.384 & 0.605 \\
\hline & & 0.332 & 0.664 \\
\hline & & $\begin{array}{l}0.355 \\
0.327\end{array}$ & $\begin{array}{l}0.657 \\
0.644\end{array}$ \\
\hline \multirow{3}{*}{$\begin{array}{c}\text { X3 } \\
\text { (Persepsi harga) }\end{array}$} & $\begin{array}{l}\text { Keterjangkauan } \\
\text { harga }\end{array}$ & 0.158 & 0.086 \\
\hline & $\begin{array}{l}\text { Kesesuaian harga } \\
\text { dengan manfaat }\end{array}$ & 0.171 & 0.148 \\
\hline & Harga kompetitif & 0.447 & 0.361 \\
\hline
\end{tabular}

Berdasarkan Tabel interprestasi koefisien korelasi pada Tabel 4 diatas, didapat kesimpulan bahwa:

1. Untuk variabel Citra merek, dimensi yang paling kuat hubungannya adalah dimensi strength of brand association terhadap dimensi Kesan / Y12 pada Kepuasan mahasiswa, karena memiliki nilai koefisien $=0.596$ (memiliki hubungan yang "Sedang")

2. Untuk variabel Kualitas pelayanan, dimensi yang paling kuat hubungannya adalah dimensi assurance/terhadap dimensi Kesan / Y12 pada Kepuasan mahasiswa, karena memiliki nilai koefisien = 0.664 (memiliki hubungan yang "Kuat").

3. Untuk variabel Persepsi harga, dimensi yang paling kuat hubungannya adalah harga kompetititf terhadap harapan / Y11 pada Kepuasan mahasiswa, karena memiliki nilai koefisien $=0.447$ (memiliki hubungan yang "Sedang").

Hasil penelitian menunjukkan bahwa Citra merek, Kualitas pelayanan dan Persepsi harga mempunyai pengaruh dan signifikan baik secara parsial maupun simultan terhadap kepuasan mahasiswa di UMT. Hal ini berarti bahwa ketiga variabel tersebut memang mempunyai pengaruh dalam upaya meningkatkan kepuasan mahasiswa UMT, dan 
sudah seharusnya hal ini menjadi perhatian penting bagi UMT. Pembahasan mengenai hasil penelitian ini adalah sebagai berikut:

\section{Pengaruh Citra merek terhadap Kepuasan mahasiswa}

Hasil uji $\mathrm{r}$ menunjukkan bahwa hubungan Citra merek dengan Kepuasan mahasiswa memiliki tingkat hubungan yang cenderung rendah hingga sedang. Sedangkan hasil uji parsial (uji t) menunjukkan bahwa Citra merek berpengaruh signifikan terhadap Kepuasan mahasiswa. Hasil ini menunjukkan bahwa jika citra merek semakin baik, maka kepuasan mahasiswa akan meningkat.

Citra universitas yang baik secara efektif akan mempengaruhi kepuasan mahasiswa jika didukung oleh berbagai upaya dari para pemegang keputusan dalam memberikan perhatian khusus dalam memasarkan citra universitas. Dengan memperbaiki citra universitas, mahasiswa akan merasa yakin bahwa universitas tempat mereka menjalankan studi adalah lembaga pendidikan yang baik dan menghasilkan lulusan yang siap diserap dunia kerja.

\section{Pengaruh Kualitas pelayanan terhadap Kepuasan mahasiswa}

Hasil uji $r$ menunjukkan bahwa hubungan Kualitas pelayanan dengan Kepuasan mahasiswa memiliki tingkat hubungan sedang. Hubungan kualitas pelayanan dengan kepuasan mahasiswa ini merupakan hubungan yang paling kuat daripada hubungan kedua variabel lainnya (citra merek dan persepsi harga) terhadap kepuasan mahasiswa. Sedangkan hasil uji parsial (uji t) menunjukkan bahwa Kualitas pelayanan berpengaruh signifikan terhadap Kepuasan mahasiswa. Hasil tersebut serupa dengan hasil penelitian dari Wahyudi. (2015) dengan hasil Kualitas pelayanan berpengaruh paling signifikan terhadap kepuasan mahasiswa dan Susanti (2014) dengan hasil bahwa kualitas layanan finansial berkorelasi positif terhadap kepuasan mahasiswa.

Kualitas pelayanan yang baik kepada mahasiswa dapat mendorong kepuasan mahasiswa. Jika penyediaan layanan mulai dari fisik seperti fasilitas bangunan kampus ataupun nonfisik seperti pelayanan staff universitas dapat ditingkatkan, maka mahasiswa akan lebih puas dan kualitas kehidupan kampus akan membaik.

\section{Pengaruh Persepsi harga terhadap Kepuasan mahasiswa}

Hasil uji $r$ menunjukkan bahwa hubungan Persepsi harga dengan Kepuasan mahasiswa, dimana keduanya memiliki hubungan paling rendah. sedangkan hasil uji parsial (uji t) memperlihatkan bahwa persepsi 
harga berpengaruh signifikan terhadap Kepuasan mahasiswa. Hasil tersebut serupa dengan hasil penelitian dari Puspa Chairun Nisa (2014) dengan hasil persepsi harga memiliki pengaruh yang positif yang signifikan terhadap kepuasan mahasiswa.

Persepsi harga yang baik akan memudahkan UMT untuk mendapatkan calon mahasiswa yang mampu untuk membiayai kuliah di UMT tanpa terkendala. Dengan persepsi harga yang baik, demonstrasi mahasiswa yang mengeluhkan biaya kuliah yang tinggi dan fasilitas yang diperoleh seharusnya tidak perlu terjadi.

\section{Pengaruh Citra merek, Kualitas pelayanan dan Persepsi harga secara simultan terhadap Kepuasan mahasiswa}

Hasil menunjukkan bahwa besarnya $\mathrm{R}$ atau korelasi besarnya variabel independen Citra merek $\left(\mathrm{X}_{1}\right)$, Kualitas pelayanan $\left(\mathrm{X}_{2}\right)$, dan Persepsi harga $\left(\mathrm{X}_{3}\right)$ secara bersama-sama terhadap variabel dependen Kepuasan mahasiswa ( $\mathrm{Y}$ ) adalah sebesar 0.815 dengan tingkat hubungan sangat kuat. $\mathrm{R}$ square atau koefisen determinan sebesar 0.665 atau $66,5 \%$, menunjukkan bahwa kepuasan mahasiswa dipengaruhi ketiga variabel independen yang dipakai dalam penelitian ini (yakni Citra merek $\left(\mathrm{X}_{1}\right)$, Kualitas pelayanan $\left(X_{2}\right)$, dan Persepsi harga $\left(X_{3}\right)$ ) sebesar $66,5 \%$, dan masih ada pengaruh dari faktor lainnya yaitu 33,5\% tidak diteliti.

Hasil uji signifikan secara simultan (uji F), menunjukkan bahwa Citra merek, Kualitas pelayanan dan persepsi harga berpengaruh secara simultan terhadap Kepuasan mahasiswa UMT. Hal ini serupa dengan hasil penelitian dari Ade Wahyudi (2015), terbukti secara parsial bahwa faktor Citra merek dan Kualitas pelayanan berpengaruh positif dan signifikan terhadap Kepuasan mahasiswa. Puspa Chairun Nisa (2014) dengan hasil persepsi harga berpengaruh positif dan signifikan terhadap kepuasan mahasiswa. Kualitas pelayanan harus ditingkatkan, terutama dalam hal penyediaan lahan parker dan internet. Persepsi harga harus diperbaiki dalam hal kesesuaian harga dengan apa yang didapatkan;

\section{Korelasi Antar Dimensi}

Hasil korelasi antar dimensi menunjukkan bahwa dari variabel citra merek, dimensi strength of brand association mempunyai hubungan yang paling kuat dengan dimensi favorable of brand association dan dibandingkan dengan dimensi uniqueness of brand association. Inti daripada dimensi strength of brand association adalah bagaimana UMT mampu menempatkan dirinya sebagai pilihan utama bagi para mahasiswa dan 
calon mahasiswa. Sedangkan untuk dimensi favorable of brand association, UMT harus bisa menjadi Universitas yang unggul di mata masyarakat.

Pada variabel kualitas pelayanan, dimensi assurance dan tangible mempunyai nilai korelasi atau hubungan yang lebih kuat daripada yang lainnya. Hal ini berarti untuk meningkatkan kepuasan mahasiswa di UMT, kualitas layanan fisik seperti fasilitas, dan kualitas pelayanan staf universitas harus menjadi perhatian daripada layanan non fisik dan assurance. Hal-hal yang perlu diperhatikan antara lain terkait dengan fasilitas parkir dan juga pelayanan staf universitas.

Pada variabel persepsi harga, dimensi harga yang kompetitif mempunyai nilai korelasi atau hubungan yang lebih kuat daripada keterjangkauan harga dan, kesesuaian harga dengan manfaat. Hal ini berarti bahwa untuk meningkatkan kepuasan mahasiswa, yang harus menjadi perhatian utama adalah memperbaiki harga yang akan dikenakan kepada mahasiswa, agar harga yang ditawarkan lebih kompetitif. Hal-hal yang perlu mendapatkan perhatian antara lain adalah uang pembangunan dan biaya kuliah per semester.

\section{E. Penutup}

Berdasarkan data yang diperoleh dan dianalisisdalam penelitian ini, dapat disimpulkan hal-hal sebagai berikut:

1) Citra merek berpengaruh nyata terhadap kepuasan mahasiswa UMT

2) Kualitas pelayanan berpengaruh nyata terhadap kepuasan mahasiswa UMT

3) Persepsi harga berpengaruh nyata terhadap kepuasan mahasiswa UMT

4) Citra merek, Kualitas pelayanan dan Persepsi harga secara bersamasama berpengaruh nyata terhadap kepuasan mahasiswa UMT

Berdasarkan kesimpulan-kesimpulan tersebut, penulis memberikan saran pada manajemen UMT dengan tujuan untuk peningkatan kepuasan mahasiswa UMT sebagai berikut:

1) Citra merek dengan dimensi favorability, strength and uniqueness of brand association perlu mendapatkan perhatian karena menyangkut dengan masa depan mahasiswa. Dengan meningkatkan citra merek, mahasiswa akan merasa lebih aman dan puas dengan studi mereka di UMT. Karena, asosiasi para lulusan dengan citra UMT akan mempengaruhi mahasiswa dalam dunia kerja. 
2) Untuk kualitas pelayanan, hal yang menyangkut pelayanan langsung kepada mahasiswa, seperti dosen dan pegawai administratif perlu mendapatkan perhatian khusus. Kualitas dosen dan karyawan universitas berpengaruh secara signifikan terhadap kepuasan mahasiswa. Keramahan dan kedekatan staf pengajar dan pelayanan dengan mahasiswa akan membuat para mahasiswa merasa percaya dan yakin bahwa UMT adalah lembaga pendidikan yang berkualitas dengan pelayanan yang prima.

3) Untuk meningkatan tingkat kompetisi UMT dalam menjangkau mahasiswa baru, maka UMT perlu melakukan perbandingan biaya studi dengan lembaga penyedia layanan pendidikan tinggi lainnya. Daya saing harga menjadi hal yang berpengaruh terhadap kepuasan mahasiswa, sehingga UMT perlu memperhatikan dan melakukan peninjauan kembali bagaimana Universitas lain menerapkan pembebanan biaya studi agar tidak mendapatkan kesan bahwa UMT adalah universitas dengan biaya yang terlalu mahal, atau sebaliknya, terlalu murah.

Saat ini, kompetisi di layanan pendidikan tinggi terus meningkat. Perguruan tinggi yang sukses adalah perguruan tinggi yang tidak hanya menghasilkan riset dan memiliki penghargaan internasional, tetapi juga perguruan tinggi yang dicintai mahasiswanya. Dengan meningkatkan kepuasan mahasiswa, diharapkan mahasiswa tidak teralihkan oleh hal-hal yang dapat mengalihkan fokus mereka dari studi dan riset. Demonstrasi akibat buruknya pelayanan, dan gejolak lainnya yang menghalangi pemberian layanan kepada mahasiswa sebaiknya ditekan dengan memberikan pelayanan dan fasilitas yang memuaskan para mahasiswa. Dengan demikian, perguruan tinggi diharapkan dapat mencetak para alumni yang berkualitas, yang sesuai dengan visi akademik perguruan tinggi, dan yang terutama bermanfaat bagi bangsa dan negara.

Saran untuk penelitian selanjutnya adalah untuk menganalisis variabel lain selain citra merek bisa ditambahkan ke dalam penelitian, karena citra merek adalah variabel yang memiliki pengaruh paling kurang signifikan. Untuk mempertajam penelitian, disarankan untuk menambah jumlah responden yang diikutsertakan. Dengan meningkatkan jumlah sampel, diharapkan nilai ketelitian penelitian bisa ditingkatkan ke 5\%. Selain itu, penelitian juga bisa difokuskan mengenai bagaimana Universitas dapat meningkatkan kepuasan mahasiswa secara langsung dengan memanfaatkan data-data faktor yang mempengaruhi kepuasan mahasiswa ini. Diharapkan dengan mempelajari metode peningkatan kepuasan 
PENGARUH CITRA MEREK, KUALITAS PELAYANAN DAN PERSEPSI HARGA

TERHADAP KEPUASAN MAHASISWA DI UNIVERSITAS MUHAMMADIYAH

TANGERANG

Ade Indra Permana, Mulky Fauzan, E Sugeng L. Prastowo

mahasiswa, perguruan tinggi di Indonesia dapat memiliki perencanaan yang lebih baik dan terstruktur dalam menghadapi kompetisi perguruan tinggi yang semakin berat baik di tingkat nasional ataupun internasional.

\section{Referensi}

Dougherty, C. (2002). Introduction to econometric 2nd ed. Oxford University Press. New York.

Gasperz, Vincent. (1997). Manajemen Kualitas, Penerapan KonsepKonsep Kualitas Dalam Manajemen Bisnis Total. PT Gramedia Utama. Jakarta.

Ghozali, Imam. (2006). Aplikasi Analisis Multivariate dengan Program SPSS. Cetakan Keempat. Badan Penerbit Universitas Diponegoro. Semarang.

Kotler, P. (2004). Manajemen Pemasaran. Edisi Millennium (Terjemahan). Jakarta: Prenhallindo.

. (2005). Marketing management. 10th ed. Prentice Hall, Inc. New Jersey.

Kotler, P., dan Keller, KL. (2008). Manajemen Pemasaran. Edisi 12. Jilid I dan II. PT. Indeks, PT Mancana Jaya Cemerlang, Jakarta. . (2006). Marketing Management. 12th ed. Prentice Hall, Inc. New Jersey. (2009). Marketing Management. 14th ed. Prentice Hall, Inc. New Jersey.

(2012). Marketing Management. 14th Global ed. Prentice Hall, Inc. New Jersey.

Kum, F. Yuen., dan Vinh, V. Thai. (2015). Service Quality and Customer Satisfaction in Liner Shipping. International Journal of Quality and Service Sciences. Vol. 7 Issue 2/3: 170-183.

Lovelock; Christoper HW., Lauren K. (2007). Manajemen Pemasaran Jasa. Terjemahan Agus Widyantoro. PT Macana Jaya Cemerlang. Jakarta.

Meenaghan, Tony., dan Shipley, David. (1999). Media effect in commercial sponsorship. European Journal of Marketing. Vol 33 Issue 3/4: 328348.

Mujianto. (2017). “Pengaruh Persepsi Harga, Kualitas Layanan dan Kepercayaan terhadap Kepuasan Pelanggan serta Implikasinya pada Loyalitas Pelanggan (Studi Kasus: Outlet Binaan Alfamart Wilayah Tangerang)". Tesis. Universitas Mercubuana. Jakarta.

141 I Pelita - Jurnal Penelitian dan Karya Ilmiah 
Mujiono, Bagus. (2014). “Pengaruh Reputasi Merek dan Kualitas Pelayanan terhadap Loyalitas dengan Variabel Intervening Kepuasan Pelanggan di RSIA Hermina Podomoro". Tesis. Universitas Mercu Buana. Jakarta.

Ngo, Vu M., Nguyen, Huan H. (2016). The Relationship between Service Quality, Customer Satisfaction and Customer Loyalty: An Investigation in Vietnamese Retail Banking Sector. Tomas Bata University in Zlin. Vietnam.

Nisa, Puspita C. (2014). “Pengaruh Kualitas Layanan Jasa Pendidikan dan Persepsi Harga Terhadap Kepuasan Mahasiswa Serta Implikasinya Pada Loyalitas (Studi Pada Mahasiswa Magister Manajemen Universitas Mercu Buana)". Tesis. Program Studi Magister Manajemen Universitas Mercu Buana, Jakarta.

Ozineh, Seyed Mehdi Hosseini. (2014). Investigating the Relationship between perceptions of pricing strategy and Consumer's Satisfaction in Insurance Industry. Kuwait Chapter of Arabian Journal of Business and Management Review. Vol. 3 No.11a.

Prasetyo, Bambang dan Linna Miftahul Jannah. 2008. Metode Penelitian Kuantitatif: Teori dan Aplikasi. PT Raja Grafindo Persada. Jakarta.

Rizwan, A; Gao L, Muhammad YR, Mudassar H. (2015). Role of Perceived Value, Customer Expectation, Corporate Image and Perceived Service Quality On the Customer Satisfaction. The Journal of Applied Business Research - July/August 2015. Vol. 31 No. 4. Lahore. Pakistan.

Sapari. (2016). "Pengaruh Kualitas Pelayanan (Tangible, Reliability, Responsiveness, Assurance, dan Empathy) terhadap Kepuasan Pelanggan pada PT. Rafindo Tiga Sakti". Tesis. Universitas Mercubuana. Jakarta.

Schiffman, L.G., dan Kanuk, L.L. (2008). Perilaku Konsumen. Edisi Ketujuh. PT Indeks. Jakarta. Sopiah dan Syihabuddin. 2008. Metode Penelitian Bisnis. Penerbit Andi. Yogyakarta.

Sulistyawati, Praba. (2011). “Analisis Pengaruh Citra Merek dan Kualitas Produk terhadap Keputusan Pembelian Laptop Merek Acer di Kota Semarang". Tesis. Universitas Diponegoro. Semarang.

Susanti, Novia. (2014). "Pengaruh Persepsi Harga, Physical Evidence dan Kualitas Layanan terhadap Kepuasan Mahasiswa Universitas Pamulang". Tesis. Universitas Pamulang. Banten.

Timothy R. Graeff. (1996). Using promotional messages to manage the effects of brand and self-image on brand evaluations. Journal of Consumer Marketing. Vol. 13 Issue: 3:4-18. 
Tjiptono, Fandi. (2006). Strategi Pemasaran. Penerbit Gramedia. Jakarta

Tjiptono, Fandi dan Chandra, Gregorius. (2011). Service Quality and Satisfaction. Edisi 3. Penerbit Andi. Jakarta.

Wahyudi, Ade. (2014). “Pengaruh Citra Merek dan Kualitas Pelayanan Terhadap Kepuasan Pelanggan Serta Implikasinya Pada Word of Mouth di Universitas Mercubuana Jakarta". Tesis. Program Studi Magister Manajemen Universitas Mercu Buana, Jakarta.

William G. Nickels. (2008). Manajemen Pemasaran Modern. Edisi kedua. Cetakan ke-tigabelas. Terjemahan Basu, Swastha DH., Irawan). Liberty Offset. Yogyakarta.

Yamit, Zulian. (2005). Manajemen Kualitas Produk dan Jasa. Ekonesia. Yogyakarta. 